\title{
Teachers Sustainable Professional Development (SPD) in Indonesia
}

\author{
Aris Munandar ${ }^{1, *}$, Ucu Cahyana $^{2}$, Budiaman $^{3}$, Suhardjo $^{1}$, Darsep $^{4}$ and Nandi \\ Kurniawan $^{5}$
}

\author{
${ }^{1}$ Pendidikan Goegrafi FIS, Universitas Negeri Jakarta \\ ${ }^{2}$ Pendidikan Kimia FIMIPA, Universitas Negeri Jakarta \\ ${ }^{3}$ Pendidikan IPS FIS, Universitas Negeri Jakarta \\ ${ }^{4}$ Pendidikan Fisika FMIPA, Universitas Negeri Jakarta \\ ${ }^{5}$ Pendidikan IPS FIS, Universitas Negeri Jakarta \\ *Corresponding author. Email: amunandar@unj.ac.id
}

\begin{abstract}
This study aims to find out Sustainable Professional Development (SPD) of the teachers after they are certified related to demographic factors which are analysed in two regions: Jakarta (capital city) and Lampung (province). A survey is conducted as the method. The population is the certified teachers with the variance: Senior High School (SMA) and Vocational School (SMK), public and private schools, A, B, C accredited schools in Jakarta and Lampung. Multistage random sampling is used as the sample collecting technique in this study. The samples are 841 SMA and SMK teachers. The study uses multiple correlations and regional comparisons as the data analysis technique. The result of the study shows a low correlation. The education level, the length of teaching and allowances have simultaneously a low correlation to Teachers Sustainable Professional Development. If a partial $t$ test is carried out the level of education that affects professional development. There are geographic differences when it comes to professional development. For Lampung (Province), they need subjects training, seminars, using applications in teaching learning process. Meanwhile, for Jakarta (capital city), they need the development in scientific publications and the innovatios in making media and art work. The result can be used as a recommendation for the central government to increase Professional Development. The program implementation is expected to be able to improve Teachers Profession appropriately.
\end{abstract}

Keywords: Education, Length of teaching, Allowances, Profession.

\section{INTRODUCTION}

In the educational sector, there has been a considerable focus on what the new "knowledge economy" requires, and how to "measure" the "success" of schooling in helping students to develop literacy and numeracy skills, in order to climb the PISA and TIMSS ladders [1]. Teachers should be evaluated routinely and supported to develop their profession by associating renumeration with performance [2]. Teachers' knowledge is gained from pre-service education when they took bachelor (S1)/diploma (D4) level. Knowledge on teaching has been proved by their pre-sevice teacher education [1]. Menawhile, their quality is improved by certification.

Teachers academic qualification is shown by a certificate issued by Institution of Educators and Education Personnel (LPTK). To be certified, teacher should take three models of certification program. The models are: (a) portfolio assessment, (b) Teacher Professional Education and Training (PLPG), and (c) Teacher Professional Education (PPG). Although PPG needs a higher cost and a longer duration (from 10 days to be 6 months), many more teachers are certified. Educator certificate taken after passing PLPG and a sufficient professional allowance taken based on an adequate people's living standard show the competence of teacher [4]. In Indonesia, the provision of the educator certificate for teachers is professional accountability, not professional responblity with the characteristics as follows: defined by current governance, standardized by contract, control, economic/legal rationale, external auditing, predetermined indicators, transparent language, framed by political goals, compliance with employer's/politicians' decisions [1]. 
The problem that arises is whether the three models of the certification program have successfully produced professional teachers. The research results showed that the pedagogical competence increased after following PLPG, but had a negative correlation with teaching performance. Therefore, it was necessary to improve the competence in teaching performance and assessment [4]. In Malang, the influence of professionalism and motivation on teacher performance occured [5]. The research results of vocational school (SMK) teachers in the north coast of Jakarta showed $43 \%$ for professional competence and $69 \%$ for pedagogic competence [6]. Applying the theoretical difference between the logic of professional "responsibility" and "accountability," the difference indicates the inherent consequences of teacher professionalism and process [1].

With economic reasons to improve welfare, certified teachers should focus on how to improve their profession. Studies in Ethiopia reveal that the absence of adequate professional payments (incentives) for teachers is a factor that reduces the value of the teaching profession in society[7]. Dealing with teaching profession, Kurniawan declared that there was a correlation between the professional incentives and the performance of high school teachers in Jakarta [8]. However, Kartini added there was a low significance between professional allowances and teaching performance of $25 \%$ [9]. Even though the figure is low, it has significant value. Meanwhile, concerning with teaching performance, the overall performance of madrasah teachers after taking certification - seen from the aspects of lesson planning, learning implementation, learning assessment, and professional development - all showed a moderate category [10]. From the evaluation research study that was conducted, the commitment of teachers who have been certified is not different from those who have not. In addition, the impact of the certification program on teacher commitment is only temporary, that is, it increases when they have just passed from the training and received a certification incentive/professional allowance [11]. These facts make the teacher certification program which is designed to improve teacher performance have not succeeded yet since the level of the performance is low to moderate.

In the technological disruptive era, the duties and demands of teachers today must be able to adapt and meet the demands of the learning needs of students in the 4.0 industrial century, which includes aspects of critical thinking, the ability to formulate and solve problems, being creative and innovative, having communication skills, mastery of digital transformation, and having abilities in multiple languages. Teachers are required to improve teaching skills, effective learning, attitudes and behavior in accordance with professional demands [12]. Responding to the industrial era 4.0, teachers are expected to always improve their competence and professional development in a sustainable manner, by participating in various training programs, seminars individually and collectively. It is necessary to do a need analysis for trainings related to professional development based on teacher performance in schools [8]. Teachers needs trainings that meet their needs, carried out systematically and comprehensively [14], trainings to equip professional skills [15].

Various programs to improve the quality of schools and the quality of teachers have been initiated by the government both in the regions and the central government.. Research conducted by Tanang [12] which linked demographic factors (age, gender, work experience and education level) with attitudes, pedagogic competence, and learning activities showed the insignificant results... Teachers need to collaborate with those who has little experience and also those with a lot of ones [16]. Therefore, this study links demographic factors (level of education and length of teaching), provision of incentives with Sustainable Professional Development (selfdevelopment, scientific publications and innovation) and how the difference between professional development of teachers in Jakarta (Java) and outside Java (Lampung) which have different local conditions and budgets.

\section{CONTEXT AND REVIEW OF LITERATURE}

One of the factors which concerns teacher education and the teaching profession is to ensure the relevance of professional development for in-service teachers[17]. The teacher profile implies the presentation of character traits and characteristics, the individual personalities shown are related to a set of norms for the teacher as a whole[18]. Law no. 14 of 2005 on Teachers and Lecturers emphasizes that teachers are professional educators who have the main task of educating, teaching, guiding, directing, training, assessing and evaluating students in early childhood education through formal primary and secondary education.

The responsibilities of a teacher include teaching and learning, administrative obligations, interacting 
(with fellow teachers, student parents) and professional development [17]. A teacher has a big and complex task and responsibility to develop the cognitive, affective, psychomotor and metacognition domains of students in order to become qualified individuals, both in terms of intellectual and moral aspects. The distribution of the tasks is explicitly as follows: 1) teaching, the teacher is responsible for teaching knowledge to students. The main focus of learning activities is to develop intellectually so that students understand the knowledge of one discipline; 2) educating students is different from teaching a science. Educating aims to change the behavior of students for the better.The process in educating students is something more difficult to do than teaching a science. In addition, a teacher should be able to be a good examplary model fo the students so that they can get good characters according to the norms and values prevailing in society; 3) training students, the teacher has skills to train students for basic skills and abilities; therefore, in vocational schools teachers provide life skills to their students; 4) guiding and directing, teachers give direction and guidance to students who worry and doubt in the process of learning and practicing, in order to stay on the right track, in this case in accordance with educational goals; 5) provide encouragement to students, the teachers job is to encourage students to try hard to be more advanced. The form of encouragement that a teacher can give to students are various, for example, giving reward verbally, orally or giving a present.

\subsection{Teachers' Sustainable Professional Development (SPD)}

Differing from traditional forms of development (such as formal courses), various initiatives are needed for reform-based initiatives (such as informal sharing sessions, action research, or peer observations) [18]. Teachers are also encouraged to spend part of their professional development time in learning about topics that are not directly related to teaching, for example counseling, multicultural education, personal well-being, or social skills [19].

Law no. 14 of 2005 on Teachers and Lecturers mandated that teaching staffs (teachers and lecturers) in Indonesia as professional positions. Certified teachers will get an extra salary as much as 1 times of the basic salary. Teacher certification has been implemented since 2007. In this year 2020, the policy has benefited the certified teachers economically. The policy of professional certification or the provision of professional allowance is a concrete form of the government recognition of teaching profession. Moreover, it can be said that this policy is also the indirect recognition from the society of teaching profession. The provision of educator's professional allowance aims not only to increase the teachers welfare, but also to develop teacher professionalism both institutionally and independently. The demand for teacher professionalism is an inevitabilty that the sustainable professional development should be done.

The problem with the profile of future teachers is an effort to develop professionalism carried out by teachers continuously, both on institutional and individual initiatives. Professionalism has an individual side, which is the professionalism of each teacher, resulting from their personal values and their conceptions of the teacher they want. The responsibility to maintain this individual professionalism lies on the teacher as individual. Sustainable Professional Development (SPD) is the development of teacher competence which is conducted in accordance with the needs, gradually, continuously to improve their professionalism (Permenneg PAN and RB No 16 in the year of 2009, article 1(5). Based on Regulation of the State Minister for Empowerment of State Apparatus and Bureaucratic Reform Number 16 of 2009 concerning Teacher Functional Positions and Credit Score, there are 3 components of teacher development, namely: a) selfdevelopment, b) scientific publications, and c) innovative works.

\subsection{Self-Development}

Self-development is an individual effort and activity carried out by teachers in order to improve their professionalism. Thus, teachers will have competencies in accordance with professional standards and regulations. It is hoped that the teacher will finally be able to carry out functional duties and obligations in learning/mentoring, including in carrying out additional tasks that are relevant to the functions of the school/madrasah. Self-development activities consist of two types, namely functional training and education and teacher collective activities. This self-development activity is intended to make teachers be able to achieve and/or improve the competence of the teaching profession which includes: pedagogical, personal, social, and professional competences as mandated in Law Number 20 of 2003 concerning the National Education System. Additional tasks that are relevant to the school/ madrasah functions, as mentioned previously, in relation to Continuous Professional Development (SPD) are oriented to the activities, which improve the competencies, in accordance with additional tasks (for example: competencies for school principals/vice principals, laboratory heads, library heads, etc). 
Functional education and training are teacher activities in participating in education or training aimed at achieving established professional competency standards and/or improving professionalism to have competencies above the established standards within a certain period of time.

\subsection{Scientific publications}

Scientific publications are scientific papers that have been published to the public as a form of teacher contribution in improving the quality of the learning process in schools, as well as the development of education world in general. Scientific publications include 3 groups of activities, namely: a) presentations at scientific forums, b) as resource persons at seminars, scientific workshops, colloqiums or scientific discussions, and c) scientific publications of research results or innovative ideas in the field of formal education. Scientific publications of research results or innovative ideas in the field of formal education comprise the composition of:

a. written paper in the form of a research report in the field of learning or education in schools which is published in the form of an ISBN book and circulated nationally or have passed the book assessment, or published in an accredited national scientific magazine/journal, at province level, and at the district/city level, or presented in a school seminar or stored in a library.

b. popular scientific writings in the field of formal education and learning in education units published in accredited national journals, non-accredited national journals, local journals (district/city/school/madrasah), etc.

c. publication of textbooks, remedial books and/or teacher guidelines. This publication includes the production of: textbooks per level or educational books per title that pass the BSNP assessment, or are printed by the publisher and have or have not an ISBN

d. learning modules for training per semester used at: the provincial level with approval from the Provincial Education Office, or the district/city with endorsement from the District/City Education Office, or the local schools/madrasahs.

e. books in the field of education are printed by publishers with ISBN and/or non-ISBNs, translated works in which of each work declared by the principal of, teacher manuals.

\subsection{Innovative work}

Innovative work is a developing work, a modification or a new discovery as a form of teacher contribution in improving the quality of the learning process in schools and (in) developing the world of education, science/technology, and art. This innovative work includes:

a. inventing an appropriate technology for complex and/or simple categories;

b. discovering/creating or developing ment of works of art for complex and/or simple categories;

c. making/modifying learning media/teaching aids/practical training equipment for complex and/or simple categories;

d. preparing quality standards, manuals, assessment of learning outcomes/questions and the like at the national and provincial levels.

\subsection{Teacher Professional Allowances}

The professional allowance as an incentive for professional teachers effectively contributes to keep the teachers on their profession as teachers and to make the teaching profession as their attractive career. In addition, allowances also play a role in motivating teachers to always improve their performance at a high level and develop their profession as a teacher [2]. The appreciation and the rewards received by teachers are of course appropriate and in line with recognition of their status.

Professional allowances as a form of additional incentives in the compensation component fall into the category of low-level needs (hygiene factors) where the professional allowances given to teachers are used to fulfill life needs other than teacher salaries and other allowances; while the professional allowances to meet high level needs (motivator factors) are closely related as a form of improvement and recognition as a professional teacher. The teacher is expected to be responsible in his/her work, be able to achieve higher achievements and always develop his/her abilities. The ingredients in the compensation component fall into the category of low level needs (hygiene factor) where the professional allowance is provided For teachers, this is used to fulfill the necessities of life in addition to teacher salaries and other allowances, while the professional allowance to meet high-level needs (motivator factors) is closely related as a form of improvement and recognition as a professional teacher. The teacher is expected to be responsible in his work, be able to achieve higher achievements and always develop his abilities.

The rewards can be divided principally into two: intrinsic rewards and extrinsic rewards. Intrinsic reward is the reward received for himself, in the form of a positive value or a sense of satisfaction with himself for completing a task which for him is quite challenging. Extrinsic rewards include direct compensation, indirect compensation and non- 
monetary benefits. Direct compensation comprises, among others, basic salary, overtime pay, incentive payments, allowances, bonuses; meanwhile, indirect compensation are, among others, social security, insurance, pensions, severance pay, work leave, training and holidays. Non-monetary rewards are the satisfaction the employee receive from the job itself or from the psychological and/or physical environment in which the employee works. This includes nonmonetary rewards such as a security or a comfortable work environment, self-development, career flexibility, opportunities for increased income, status symbols, praise and recognition.

Performance allowances are part of direct compensations. Regional performance allowances are compensation provided in each region to employees under their leadership. Each region has a nominal difference in the regional allowance. The amount of the regional allowance depends on the Regional Budget (APBD) respectively. If the region has a large source of income, the regional performance allowance is large, for example Jakarta. The amount of the regional performance allowance is stated in the governor's regulation. The research study was taken in two different areas of TKD (Regional Performance Allowance). TKD in Jakarta is set forth in the 2017 governorate regulation in 2014, while in Lampung it is stated in the 2017 Governor Regulation. The amount of allowance depends on rank and class can be seen in Table 1.

Table 1. The amount of Regional Performance Allowance (TKD)

\begin{tabular}{llll}
\hline No & Grouping & Jakarta & Lampung \\
\hline 1 & III a & $\operatorname{Rp~4.753.750~}$ & Rp 1.150.000 \\
\hline 2 & III b & Rp 4.753.750 1.200 .000 \\
\hline 3 & III c & $\operatorname{Rp~4.985.000~}$ & $\operatorname{Rp~1.250.000~}$ \\
\hline 4 & III d & $\operatorname{Rp~4.985.000~} 1.300 .000$ \\
\hline 5 & IV a & $\operatorname{Rp~5.216.250~}$ & $\operatorname{Rp~1.500.000~}$ \\
\hline 6 & IV b & $\operatorname{Rp~5.216.250~}$ & Rp 1.600.000 \\
\hline 7 & IV c & $\operatorname{Rp~5.447.500~}$ & Rp.1.750.000 \\
\hline 8 & IV d & $\operatorname{Rp~5.447.500~}$ & Rp. 2.000.000 \\
\hline 9 & IV e & Rp 5.447.500 & Rp. 2.500.000 \\
\hline
\end{tabular}

\section{METHOD}

The research method used in this study is a survey. Population of this study is SMA and SMK teachers at public and private schools, in Jakarta and Lampung provinces, the details are presented in Table 2:

Table 2. Population at Research Region

\begin{tabular}{|c|c|c|c|c|}
\hline \multirow{2}{*}{ Population Region } & \multicolumn{4}{|c|}{ Quantity } \\
\hline & $S M A$ & Teachers & $S M K$ & Teachers \\
\hline Jakarta & 493 & 5280 & 579 & 3668 \\
\hline Lampung & 503 & 5833 & 491 & 3648 \\
\hline Total & 996 & 11113 & 1070 & 7316 \\
\hline
\end{tabular}

(http://dapo.dikdasmen.kemdikbud.go.id)

The technique of sampling used in this study is Multistage random sampling which can combine the other techniques [20]. First stage, the region of sampling is determined on the basis of city/district (kota/kabupaten) in both provinces. For DKI Jakarta it took three cities/districts, while in Lampung 2 cities/districts. Among the five cities/districts, the next step is to identify the status of SMA and SMK, public or private schools and the level of school accreditation (A, B, or $\mathrm{C}$ ). Based on the monogram of Herry King which has the significanc level of 5\%, this study took 841 SMA and SMK teachers as the samples.
The operational variables of teacher demographic factor are education $\left(\mathrm{X}_{1}\right)$, length of teaching $\left(\mathrm{X}_{2}\right)$ and allowances $\left(\mathrm{X}_{3}\right)$ as the independent variables and the teachers' sustainable professional development $(\mathrm{Y})$ is as the dependent variable. The data were collected by a quetionnairre with Gutman scale (yes and no). The data analysis technique is multiple correlation. The normality assumption and freedom from the classical assumption (multicollinearity, heteroscedasticity) were conducted previously. In addition, the study conducted the comparative analysis between two different geographic regions to know the Sustainable 
Professional Development. The variables of this study

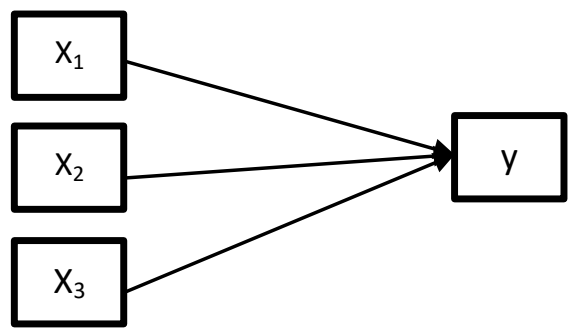

are presented in Figure 1.

$$
\begin{aligned}
& \mathrm{X}_{1}=\text { education level } \\
& \mathrm{X}_{2}=\text { length of teaching } \\
& \mathrm{X}_{3}=\text { allowances } \\
& \mathrm{Y}=\text { Teachers' Sustainable Professional } \\
& \text { Development }
\end{aligned}
$$

Figure 1. Correlation between $\mathrm{X}$ and $\mathrm{Y}$ variables

\section{FINDINGS}

The result of the study shows that the regression model distributed normally because the model followed data plotting (dot/plot) describing the real data. The multicollinearity test with provisions explains that the multicollinearity symptoms did not happen since the tolerance value is above 1 and VIF value below 10, see Table 3 .

Table 3. Multicollinearity Test

\begin{tabular}{lll}
\hline Variable & Tolerance Value $>0,100$ & VIF Value $<10,00$ \\
\hline$X_{1}$ & 0,965 & 1,036 \\
\hline$X_{2}$ & 0,971 & 1,030 \\
\hline$X_{3}$ & 0,993 & 1,007 \\
\hline
\end{tabular}

Source: Data Processing, 2020

Heteroscedasticity test is conducted if there is an unclear pattern in the figure of scatterplots and the dots scatter above and under value 0 at $\mathrm{Y}$ axis. The result of the study shows that the heteroscedasticity was not found.
The partial t-test was conducted to see the selfinfluence $\mathrm{X}$ variable toward $\mathrm{Y}$. If the value of Sig $<0.05$, it has an effect. See Table 4.

Table 4. Partial Test

\begin{tabular}{lll}
\hline Variable & Value of sig $<0,05$ & Explanation \\
\hline $\mathrm{X}_{1}$ & 0,000 & Take an effect \\
$\mathrm{X}_{2}$ & 0,222 & No effect \\
$\mathrm{X}_{3}$ & 0,031 & No effect \\
\hline
\end{tabular}

Source: Data Processing, 2020

Partially, the test showed that $\mathrm{X}_{1}$ had affected $\mathrm{Y}$, while $\mathrm{X}_{2}$ dan $\mathrm{X}_{3}$ had not affected $\mathrm{Y}$. If value of sig $<0,005$, simultaneous $\mathrm{F}$ test is conducted. The calculation shows that value of Sig 0,000 . It can be concluded simultaneously that $\mathrm{X}$ variable affected to
$\mathrm{Y}$ variable. To find out the extent the relation $\mathrm{X}$ to $\mathrm{Y}$,

\begin{tabular}{|c|c|c|c|c|c|}
\hline \multirow[b]{2}{*}{ Model } & \multirow[b]{2}{*}{$\mathrm{R}$} & \multirow[b]{2}{*}{ R Square } & \multicolumn{3}{|c|}{ Std. Error of the } \\
\hline & & & Adjusted R Square & Estimate & Durbin-Watson \\
\hline 1 & $.318^{\mathrm{a}}$ & .10 & .09 & & 1.619 \\
\hline
\end{tabular}
it can be seen from value of $\mathrm{R} 0.318$. If adjusted to the value of $R$, it has a weak correlation $(0.21$ to 0.40). See Table 5.

Table 5. Model Summary

a. Predictors: (Constant), Allowances, Length of teaching, Education

b. Dependent Variable: Professional Development

The following chart is about Sustainable Professional Development in two different regions in
Jakarta and Lampung. In general, the chart has the similar graphics. Overall, the indicators that the 
percentage below $50 \%$ are in further studies, becoming a resource for scientific activities, using programs such as multimedia, pigure and using evaluation programs in learning. In Jakarta several indicators of personal development are superior to Lampung in terms of further studies, field training, seminars, use of ITC with presentations and evaluations. Other indicators between Jakarta and Lampung have almost the same results. The following is the graph of self-development in Jakarta and Lampung. See Figure 2.

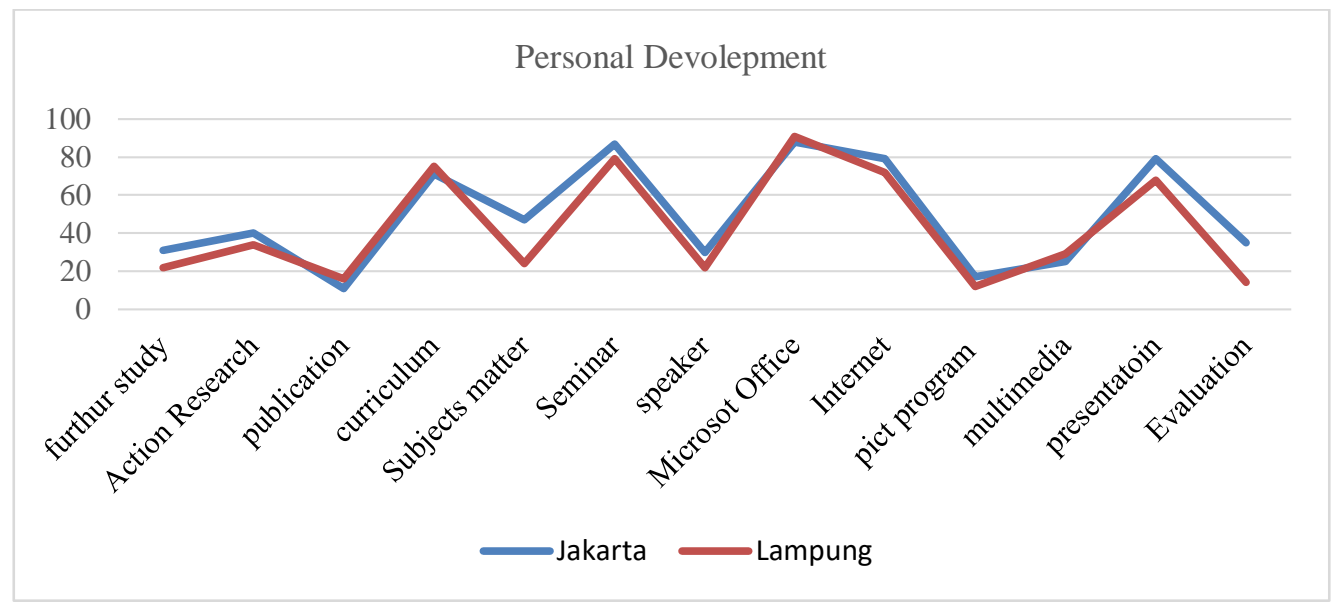

Figure 2. Graph of Personal Development (Source: Data Processing, 2020)

The variable of scientific publication has similar forms between Jakarta and Lampung. In general, the lowest percentage in scientific publication is the indicators of journal publication and book. Lampung has the higher amount in research and classroom action research (CAR/PTK). Both regions have the similar percentage in publication: journal, LKS (school worksheets), book. Figure 3 is the graph of scientific publication in Jakarta and Lampung.

\section{Scientific Publication}

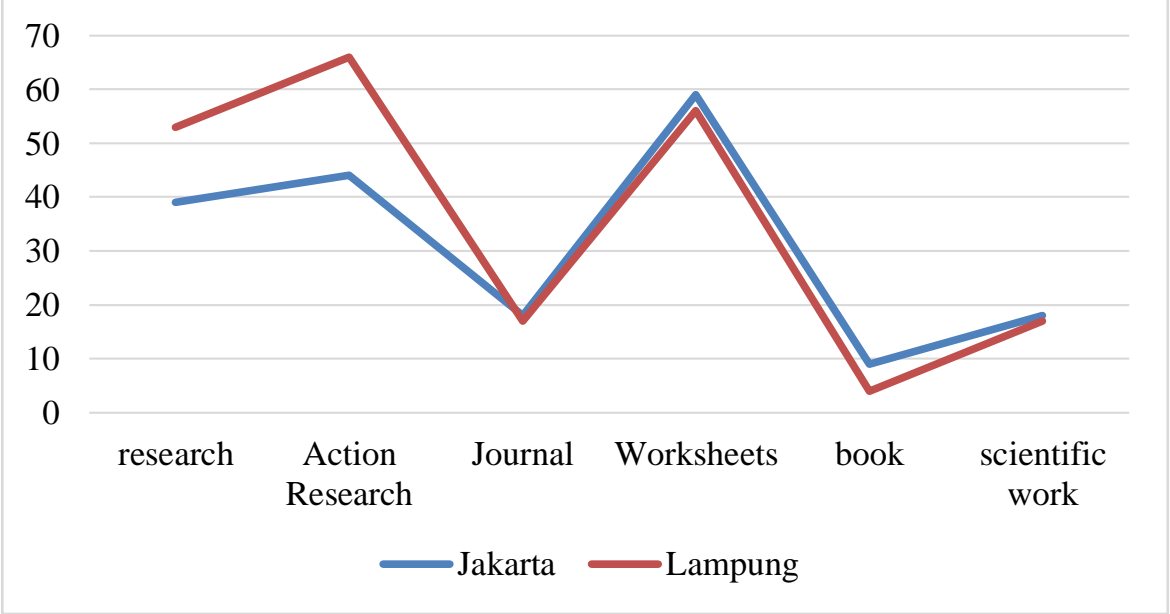

Figure 3. Graph of Scientific Publication (Source: Data Processing, 2019)

The variable of innovative works, in general, also has the similar form. The two regions of teachers did few innovative works, below $20 \%$ for all indicators. Lampung has a little bit superior than Jakarta in the works: art works, teaching media (prop) and procedure preparation. The graph of innovative works in Jakarta and Lampung is presented in Figure 4. 


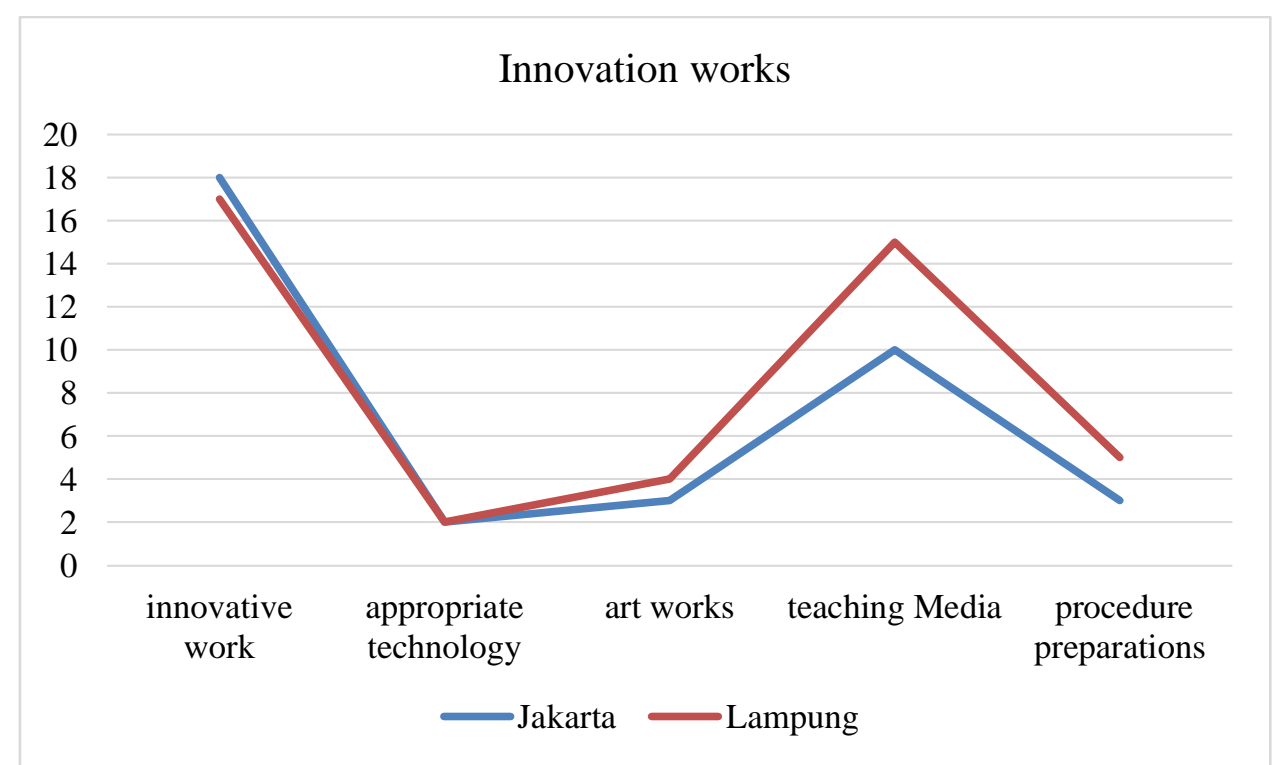

Figure 4. Graph of Innovative Works (Source: Data Processing, 2020)

\section{DISCUSSION}

It is found that there is a weak correlation between education, teacher experience and allowances and the sustainable professional development. It can be interpreted that teachers have higher education, a large allowance, long teaching experience, but still have low professional development. In general, the average figure is below 50 percent. This result is different from the results of study by Tanang [12] which states that there is no correlation between demographic factors and the development of teacher competence, both professional, pedagogic, personal and personality.

When a separate test is conducted for education level which is included in demographic element affecting professional development, there is a correlation but weak. The result is supported by a research which presented that education qualification affected significantly to the professionalism of IPS (social) teachers at SMP in Kabupaten Gowa. This is proved by the significant value [21]. The other research declared that the education qualification, innovative attitude and ethos affected to the improvement of teacher professionalism [22]. Setiawan found that education level and teaching experience correlated to teacher's creativity, but not the income [23]. In contrast to the results of other studies, Leonard [13] stated that there is an indirect effect between the compensation the teachers received and their performance throughout the teacher competence. It can be concluded if it is tested separately or together with the other variables, education (level) will affect professionalism, competence, creativity and others.

The partial test of length of teaching did not correlate to professionalism building. This is appropriate with the study showing that the experienced teachers are not guaranteed for having professional ethics [24]. Ideally, teachers, who already had got higher education and large allowances, have higher self-development, more scientific publications and innovative works. The low value of the relationship requires efforts to improve their professional development. The allowances from government should be used maximally to personal or self-development such as the investment in the form of continuing their study for those who still got undergraduate level (S1), be active in scientific activity e.g., training, workshop, scientific publication in the form of an article or being a resource person, making an innovative work. However, the allowances are used for other purposes. The professional allowance is spent to the consumptive activities, fulfill the primary needs. The allowance as an additional form of incentive in the compensation component is included in the category of low-level needs (hygiene factor) in which the professional allowance for teachers is used to fulfill life needs in addition to teacher salaries and other allowances

Government of Indonesia has a higher education budget $(20 \%)$ than the countries united in OECD (10.9\%) [2]. Jakarta that has Regional Performance Allowance (TKD) makes the average salary of 
teachers in DKI Jakarta as much IDR10.927.0000 per month, the lowest is IDR2.577.0000 and the highest IDR 20.950.000. This allowance should have made teachers active in scientific activities as a participant, a resource person in any activities that can improve their professional abilities. They should be able to use any IT applications to support their profession encountering industrial era 4.0. Teachers should not be trapped any more in chasing the number of hours because, in accordance with the provision, the minimum hours of teaching are 24 lesson hours a week. Then, the rest of hours can be used by the teachers to develop themselves through innovation and publication. The differentiation of the two regions is carried out considering that Jakarta is the capital of the state, each teacher under the regional government gets TKD (Regional Performance Allowance) in accordance with the Governor Regulation whose value differs between the two study areas.

\subsection{Personal/Self-Development}

The answer of not continuing study as the teacher's response in implementing further studies (master or doctoral) after passing certification was the most. Between $20-30 \%$ of teachers decided to continue their study at a higher level. Jakarta, in this case, has a higher percentage in further studies because Jakarta has more universities than in Lampung (Jakarta 50, Lampung 14). Teachers in Jakarta have more opportunities to continue their studies with many university choices. Meanwhile, teachers in Lampung will no longer continue to pursue higher education levels; they are satisfied with the S1 level as a minimum requirement to be a teacher. Academic qualification is the minimum level of education that must be fulfilled by an educator as evidenced by a diploma or certificate of expertise regulated by law. The certificate that a teacher must have is a bachelor's degree or Diploma IV in accordance with the type, level and educational unit or subject being taught. There are differences in the subject matter of SMA and SMK education units. The survey results show that at least teachers have met the minimum standard of academic qualifications. These results are in accordance with the results of study showing that educational qualifications, innovative attitudes and ethos have an effect on increasing teacher professionalism [22].

In the last five years, the trainings the teachers mostly followed are the implementation of curriculum 2013 (K13), classroom action research (PTK) trainings, subject field trainings, trainings for scientific writing/publication. The 2013 curriculum training was held by district/city and provincial offices. The dissemination of the 2013 curriculum is often done as an effort to understand and to do the curriculum. In accordance with the implementation of the 2013 curriculum, all schools are obliged to implement it. This enforcement requires all teachers to take part in the 2013 curriculum training. Therefore, taking the 2013 curriculum training is the most answer. These results are in accordance with the studies that were conducted previously: Indonesian language teachers are ready for the implementation of the 2013 Curriculum [24]; The teacher is ready to implement the curriculum [25]; Teachers have high readiness in curriculum implementation [26], teachers are ready to implement the 2013 curriculum [27].

The next most likely answer that the teacher participated in was Classroom Action Research Training. Teachers attend CAR training for promotion because of the enactment of the Regulation of the Minister of State for the Utilization of State Apparatus and the Reform Bureaucracy Number 16 of 2019 concerning teacher functional positions and credit scores. The essence of the regulation is that every teacher will annually be assessed for their performance and carry out continuous professional development which has an impact on the number of credits collected for the higher ranks. One of the professional developments is scientific publications obtained from CAR activities. CAR is one of the teacher's efforts to solve problems faced in classroom learning with the scientific method. Improvements in learning in the cycle are expected to increase teacher teaching and learning activities in each class. CAR is not a priority for teachers to implement, there is no system that declares the results of CAR teachers is not only as an administrative requirement. The results of the CAR did not really answer the needs in the field. There are two motivations for teachers to do CAR: to improve the quality of learning and to fulfill the requirements for completing the undergraduate level [28].

Subject field trainings and scientific publication trainings are rarely conducted because they are not urgent for teachers. Jakarta is higher than Lampung in subject-field training because there are so many fields of science that hold training activities. This result is appropriate with the result of study which states that socalled "suburban" schools that are away from university cities or large cities seem to consider the formal competency development to be problematic. Geographical distance makes teachers difficult to attend courses.

Many fields of study training collaborate with MGMP (Subject Teacher Group Discussion). The 
capacity development achieved by expanding the content of knowledge and the quality of teaching and the diverse learning carried out by High School Teachers in Jakarta are very high [8]. Teachers obtained satisfaction from sharing experiences with their colleagues [29].

Most of the education and trainings which are held are about the 2013 Curriculum. Teachers who participate in the trainings are uneven because they feel that there are not many trainings being held, trainings that do not meet their needs. In-service training does not contribute to some teachers and their personal development [15]. It needs a training rationing per teacher in both Jakarta and Lampung. Teachers in Singapore are given a very high ration of 100 voluntary hours per year for their professional development [18]. Training in accordance with teacher needs is very important. The results of the study showed that there was an effect of teacher education and training on teacher performance. Teacher training in Jakarta affects teacher performance [30].

Teachers who rarely become a resource person indicate that their ability in self-development has not been maximized. Teachers cannot develop scientific or educational content to share with their peers in seminars or other activities. It is necessary to increase the ability of teachers to collaborate as resource persons in various scientific and pedagogical disciplines. Teacher collaboration can improve leadership and learning quality [31]. The collaborative teacher should be able to solve problems in learning through the CAR process, then it can be developed in publication activities or become a resource person, a person who can provide inspiration or socialization to others. The CAR conducted is pragmatic, for promotion needs only. The low number of research publications show serious problems in selfdevelopment activities.

Computer application programs that teachers use in learning activities in Jakarta and Lampung have almost the same results, only at the basic level, in the form of Microsoft office programs, presentation programs (MS powerpoint, lectora), internet applications (yahoo.com, gmail.com). Other programs are a bit multimedia (Winamp, GOM Player), evaluation application programs (kahoot, google form), image processing programs (Corel Draw, Photoshoop). The constraints to the use of ICT in Aceh (Outer Java island) Indonesia are due to the advanced age of teachers, expensive media costs, limited facilities owned by schools, the number of students who are too large in class, have never been given training in using computers in schools, are unable to use computers [32]. Research findings on teachers' ICT utilization in Malaysian schools are low; according to the ministry, the finding shows that $80 \%$ of teachers spend less than one hour a week using ICT. Only one-third of students think their teacher uses ICT regularly [33]. According to UNESCO, the findings presented "that when ICTs were used in teaching, in many cases did not go far beyond the use of PowerPoint as an instructional tool". The findings also indicate the lack of use of ICTs in education and teacher skills. In addition, ICT Knowledge and Operations have not reached the required competencies and therefore teachers are not motivated to use them in the classroom. The use of ICT is an important scale in personal professional assessment [34].

\subsection{Scientific Publications}

Publication activities in Lampung in the form of research and CAR are higher than in Jakarta; while for journals, the making of worksheets is almost the same. Teachers in Lampung have higher publicity. Following new trends identified in innovative Anglo-Saxon schools, the Teachers Network designs and implements a series of interconnected programs to facilitate teacher collaboration, reflection and inquiry [19]. The main learning platform is called the "Learning Circle," where small groups of independent teachers engage in activities such as action research. Drawing on the knowledge built into these learning circles, teachers then engage in other programs such as teacher-led workshops. Teachers theoretically understand CAR, but have difficulty in developing and determining research instruments in data collection [28]. Although CAR training has been carried out in East Jakarta, assistance must always be provided [35]. CAR ability is improved by using peer tutors [36].

\subsection{Innovative Work}

The innovative work produced by teachers in Jakarta and Lampung is equally low at under $20 \%$. Many teachers do not innovate in their learning. For those who carry out learning innovations, the innovations are in the form of teaching aids, preparation of SOPs, works of art and appropriate technology. The low level of innovative work needs to be improved considering the different environmental characteristics of each region, so that it requires teachers to be able to innovate with their respective circumstances. Innovative attitudes have a significant effect on the professionalism of social studies teachers in junior high schools in Gowa Regency [22]. Teachers must have an innovative attitude to develop the 
existing potential of students so that students are able to face the current development [37].

The striking difference in Lampung is that teachers make more teaching aids compared to Jakarta, the creative power in Lampung is higher in making teaching aids, limited facilities and infrastructures stimulate teachers to be able to make learning media that can convey messages. Teachers can make teaching aids that are contextual to the surrounding environment, using local wisdom as an effort to preserve the environment appropriately. Teachers can create specific and unique works of art in each region. The low use of media is in accordance with the results of the study that the use of media is low so that teachers have to increase their knowledge of learning media; the principal proposes the procurement of completeness of learning media in schools, on the other hand the education office makes trainings for teachers [38]. Difficulties in using media are due to limited availability, time, costs and personnel [39]. Media development is in accordance with the 2020-20 Ministry of Education and Culture Strategic Plan, which is to provide material to develop teacher competence and quality and standard media/teaching aids. Learning resources with the OER (Open Educational Resources) system allows teachers to use them as research teaching resources without prior permission.

There are differences in terms of Sustainable Professional development in the two study areas. These results can be used as recommendations in Java (Jakarta) and outside Java (Lampung) in increasing their professional development. These findings become a model for the types of activities that can be carried out in different geographical conditions. For areas outside Java, training in the field of study, seminar activities, the use of applications in learning, activating MGMP is required. For the Jakarta area, it is necessary to increase in scientific publications and innovations in media and art creation. The implementation of the program is expected to increase teachers' professionalism. Professionalism is a lifelong and endless process for a professional teacher [3]. Concerning with the teacher's performance, the performance can be increased with motivation and professional allowances simultaneously [9]. In order to achieve a degree of professionalism, a teacher requires a professional process with pre-service education, inservice education including training, a guidance from teacher professional organizations, the enforcement of professional ethics, certification, the improvement in the quality of prospective teachers, and the amount of salary [40]. There are several types of activities that teachers can undertake, ranging from formal/structured courses and programs to more informal/reform-based initiatives (action research, lesson studies) [18].

\section{CONCLUSION}

The result of the study shows that there is a simultaneous relationship among education level, the length of study, allowances and Teachers' Sustainable Professional Development with the value $\mathrm{r} 0.315$, although it is included low. Partially, only education level affects, while the provision of allowances and the length of study do not. Teachers both in Jakarta and in Lampung should improve their Sustainable Professional Development. Teachers in Jakarta with the higher Regional Performance Allowance have a big opportunity in developing Sustainable Profession. Teachers in Jakarta are more superior in continuing their study (having many universities), training on fields of study, participating in seminar, using ICT. Meanwhile, teachers in Lampung are more superior in research, CAR, making art works, media and SOP. These results can be used as models to determine the types of activities in province in improving the Sustainable Professional Development. Teachers in province are encouraged to continue their study, to take trainings on fields of study, to participate in seminar and to improve ICT.

\section{REFERENCES}

[1] Solbrekke, T. D., \& Englund, T. (2014). Certification of teachers: Tensions in a new signature reform. Professions and Professionalism, 4(2), 1-13.

[2] OECD, 2018, Survey Ekonomi OECD Indonesia 2018, OECD

[3] Priansa, D. J. (2014). Kinerja dan Profesionalisme Guru: Fokus pada Peningkatan Kualitas Sekolah, Guru, dan Proses Pembelajaran. Bandung: Alfabeta.

[4] Yusnita et al., "The Effect of Professional Education and Training for Teachers (PLPG) in Improving Pedagogic Competence and Teacher Performance," Tadris J. Kegur. dan Ilmu Tarb., vol. 3, no. 2, p. 123, 2018, doi: 10.24042/tadris.v3i2.2701

[5] Dewi, Tiara. Anggia, 2014, Pengaruh Profesionalisme Guru dan Motivasi Kerja terhadap Kinerja Guru Ekonomi SMA Sekota Malang, Jurnal Promosi Jurnal Pendidikan Ekonomi UM Metro ISSN: 2442-9449 Vol.3.No.1 (2015) 24-35.

[6] Bunyamin, 2016, Teacher Profesionalism: A Study on Theacher'Professional and Pedagogic Competence at Vocational Highs Scholls In the 
North thernCoastal of Jakarta IJER, Vol. 2 No 1.1 Juni 2016, Publisher PPS UNJ.

[7] Gemeda, F. T., \& Tynjälä, P. (2015). Exploring Teachers' Motivation for Teaching and Professional Development in Ethiopia:Voices from the Field. Journal of Studies in Education, 5(2), 169.

[8] A. Kurniawan, "Tunjangan Profesi, Pendidikan Dan Latihan Profesi (Plpg) Dalam Kinerja Guru Sma," J. Adm. Pendidik., vol. 25, no. 2, pp. 324335, 2018, doi: 10.17509/jap.v25i2.15645.

[9] D. Kartini and M. Kristiawan, "Pengaruh Tunjangan Profesi dan Motivasi Kerja Terhadap Kinerja Guru," Kelola J. Manaj. Pendidik., vol. 6, no. 1, pp. 25-33, 2019, doi: 10.24246/j.jk.2019.v6.i1.p25-33.

[10] Khodijah, N. (2013). Kinerja guru madrasah dan guru pendidikan agama Islam pasca sertifikasi di Sumatera Selatan. Yogyakarta: Jurnal Cakrawala Pendidikan.

[11] Suardi, W., \& Yusuf, S. (2017). Program Sertifikasi dan Komitmen Guru: Aplikasi Regression Discontinuity Design (RDD).

[12] H. Tanang and B. Abu, "Teacher Professionalism and Professional Development Practices in South Sulawesi, Indonesia," J. Curric. Teach., vol. 3, no. 2, pp. 25-42, 2014, doi: 10.5430/jct.v3n2p25.

[13] Leonard, 2009, Kinerja Guru Di DKI

Jakarta, Suatu Tinjauan Terhadap

Kompetensi dan Kompensasi Yang

Diterima Oleh Guru di DKI Jakarta)

Diseminarkan dalam Seminar Nasional

Matematika Universitas Parahyangan

Bandung, 5 September 2009.

[14] Leonard, 2015, Kompetensi Tenaga Kependidikan di Indonesia, Analisis Dampak Rendahnya Kualitas SDM Guru dan Solusinya, Jurnal Formatif 5(3): 192-201, 2015

[15] Tuncel, Z. A., \& Çobanoğlu, F. (2018). Inservice Teacher Training: Problems of the Teachers as Learners. International Journal of Instruction, 11(4), 159-174. https://doi.org/10.12973/iji.2018.11411a

[16] Copriady, J., Zulnaidi, H., Alimin, M., \& Rustaman. (2018). In-service Training for Chemistry Teachers' Proficiency: The Intermediary Effect of Collaboration Based on Teaching Experience. International Journal of Instruction, 11(4), 749-760. https://doi.org/10.12973/iji.2018.11447a

[17] Lim Kam Ming, 2014, Theacher Education \&Theaching Profession inSingapure, Conference Paper, Okotber 2014

[18] Bautista, A., Wong, J., \& Gopinathan, S.
(2015). Teacher professional development in Singapore: Depicting the landscape. Psychology, Society and Education, 7(3), 311326.Bolden, R., Gosling, J., Marturano, A. \& Dennison, P. (2003). A review of leadership theory and competency frameworks. Edited version of a report for Chase Consulting and the Management Standards Centre. Exeter: Centre for Leadership Studies University of Exeter.

[19] Tripp, D. (2004). Teachers' networks: A new approach to the professional development of teachers in Singapore. In C. Day \& J. Sachs (Eds.), International handbook on the continuing professional development of teachers (pp. 191-214). Maidenhead

[20] Barreiro, P. L. \& Justo, P. A. (2001) Management mathematics for european schools. population and sample sampling techniques. Diakses tanggal 13 November 2016, dari http://www.mathematik.unikl.de/ mamaeusch.

[21] Awe, E. Y. (2014). Hubungan antara kualifikasi akademik, kompetensi, motivasi kerja dengan kinerja gurum sekolah dasar (sd) di kecamatan bajawa, kabupaten ngada. e-Journal Program Pascasarjana Universitas Pendidikan Ganesha, Program Studi Pendidikan Dasar, 4.

[22] Syamsuriyanti, Sutirno, (2017), Faktor Determinasi Profesionalisme Guru, Harmoni Sosial: Jurnal Pendidikan IPS, Volume 4, No 2, September 2017 (197-211)

[23] Setiawan, R. (2017). The Influence of Income, Experience, and Academic Qualification on the Early Chilhood Education Teachers' Creativity in Semarang, Indonesia. International Journal of Instruction, 10(4), 39-50. https://doi.org/10.12973/iji.2017.1043a

[24] Pujiono, Setyawan, 2014, Kesiapan Guru Bahasa Indonesia SMP dalam Implementasi Kurikulum 2013, Litera, Volume 13, Nomor 2, Oktober 2014

[25] Kafi, Z., Motallebzadeh, K., \& Ashraf, H. (2018). University Instructors' Teaching Experience and Their Perception of Professional Ethics: Postulating a Model. International Journal of Instruction, 11(4), 257-270. https://doi.org/10.12973/iji.2018.11417a

[26] Kristiantari, Rini.MG, 2014, Analisis Kesiapan Guru Sekolah dalam Mengimplementasikan Pembelajaran Tematik Integratif Menyongsong Kurikulum 2013, Jurnal Pendidikan Inonesia, Vol. 3, No. 2, Oktober 2014, ISSN: 2303-288X

[27] Hidayah Isti, Pristiwati . Rahayu, Widiyatmoko. Arif, 2015, Kajian Kesiapan Guru Mata Pelajaran Matematika, Bahasa Indonesia, dan 
IPA SMP dalam Implementasi Kurikulum 2013 di Kota Semarang, Jurnal Penelitian Pendidikan, Vol. 32 Nomor 2 Tahun 2015

[28] Badhayanti. Clara Ika Sari, 2018, Peningkatan Kompetensi Guru SD dalam Melaksanakan Penelitian Tindakan Kelas, Jurnal Bakti Masyarakat Indonesia, Vol. 1, No. 2, November 2018, Hal. 91-101

[29] Koutrouba, K. \& Michala, M. (2017). Professional Satisfaction of Secondary Education Teachers: The Case of Greece. International Journal of Instruction, 10(2), 85102. https://doi.org/10.12973/iji.2017.1026a

[30] Santoso. Budi, Suharno, 2007, Pengaruh Pelatihan dan budaya Organisasi terhadap kinerja guru Sekolah Menengah Pertama (SMP) Negeri di DKI Jakarta, Jurnal Penelitian Pendidikan, Vol. 6 No. 11Juli, 2007

[31] Ismail, S. N., Muhammad, F., Kanesan, A. G., Yaacob, A., \& (2018). Teacher Collaboration as a Mediator for Strategic Leadership and Teaching Quality. International Journal of Instruction, 11(4), 485-498. https://doi.org/10.12973/iji.2018.11430a Jurnal Ekubis, 1(2), 1-18.

[32] Soewarno, Hasmiana, Faiza, 2016, KendalaKendala yang di Hadapi Guru dalam Memanfaatkan Media Berbasis Komputer di SD Negeri 10 Banda Aceh, Jurnal Pesona Dasar, Vol. 2 No.4, April 2016, 28 -39.

[33] Ziden, Azidah A, Fook, Soon F, Konghoong, Boey G, Rahman, Andul M.A , 2017, Malysian ICT Comprehensive Competency Standards For Theachers, Journal of Theoretical and Applied Information Technology, 30th April 2017. Vol.95. No 8
[34] Balbağ, M. Z., Yenilmez, K., \& Turgut, M. (2017). Personal Professional Development Efforts Scale for Middle School Mathematics Teachers: An Adaptation Study. International Journal of Instruction, 10(4), 325-342. https://doi.org/10.12973/iji.2017.10419a

[35] Wiganda. Supria, 2014, Pelatihan Penelitian Tindakan Kelas Bagi Guru-Guru Se Jakarta Timur, Jurnal Sarwahita Volume 11 No. 1, 2014

[36] Wiyono, 2020, Upaya Meningkatkan Kemampuan Penelitian Tindakan Kelas Melalui Tutor Sebaya, Lembaga Pengembangan Pemberdayaan Kepala Sekolah (LPPKS)

[37] Zuljan, M.V \& Vogrinc, J. (2010). Facilitating effective student learning through Teacher Research and Innovation. Slovenia: Faculty of Education, University of Ljubljana.

[38] Alwi, Said, 2017, Problematika Guru Dalam Pengembangan Media Pembelajaran, Itqan, Vol. 8, No. 2, Juli - Desember 2017

[39] Supriyati, 2013, Pemanfaatan Media Pembelajaran Geografi SMA di Kabupaten Sleman, Skripsi, Program Studi Pendidikan Geografi, Fakultas Ilmu Sosial, Universitas Negeri Yogyakarta, 2013

[40] Suprihatiningrum, J. (2014). Guru profesional, pedoman kinerja, kualifikasi \& kompetensi guru. Yogyakarta: Ar-Ruzz Media. 